\title{
Calving of Fuerza Aérea Glacier (Greenwich Island, Antarctica) observed with terrestrial laser scanning and continuous video monitoring
}

\author{
MICHAŁ PECTLICKI, ${ }^{1}+$ CHRISTOPHE KINNARD ${ }^{2}$ \\ ${ }^{1}$ Institute of Geophysics, Polish Academy of Sciences, ul.Księcia Janusza 64, 01-452 Warsaw, Poland \\ ${ }^{2}$ Département des sciences de l'environnement, Université du Québec à Trois-Rivières, 3351, boul. des Forges, C.P. 500, \\ Trois-Rivières G9A 5H7, Canada \\ Correspondence: Michał Pętlicki <petlicki@igf.edu.pl>
}

\begin{abstract}
A short-term series of quantitative observations of calving activity of Fuerza Aérea Glacier (Greenwich Island, the South Shetland Islands, Antarctica) was conducted in order to test new methods of monitoring calving. The volume of single calving events was quantified by combining terrestrial laser scanning (TLS) surveys with continuous video recording of the ice front. An empirical formula for area/ volume scaling of the calved ice block was proposed based on the TLS measured calved ice volume and the calved ice front area obtained by manual delineation on the images acquired with the video camera. This combination of methods proves to be a valuable tool for glacier monitoring, providing both hightemporal resolution and precise quantitative measurements of the calving volume. The size distribution of calving events is best approximated by a power law and within the short period of observations (14 d) calving was found to be an intrinsic process not dependent on environmental forcings. Over the period of 21 January-04 February 2013 the ice flow velocity at the terminus of Fuerza Aérea Glacier was $0.26 \pm$ $0.07 \mathrm{~m} \mathrm{~d}^{-1}$ and the calving rate was $0.41 \pm 0.07 \mathrm{~m} \mathrm{~d}^{-1}$.
\end{abstract}

KEYWORDS: Antarctic glaciology, calving, glacier monitoring, glaciological instruments and methods

\section{INTRODUCTION}

Calving is one of the most important processes in the mass loss of glaciers; it is a major contributor to the observed and predicted sea-level (Benn and others, 2007b). Recent estimates show that it contributes $\sim 50 \%$ of the mass loss of the Antarctic (Rignot and others, 2013) and Greenland (van den Broeke and others, 2009) ice sheets and is expected to increase even more with climate warming. Despite rapid advances in modelling and field observations, there is still a large knowledge gap concerning the triggering of particular calving events. One of the reasons for this is a deficiency of detailed quantitative observations of such events, especially those of a smaller size. Most of the focus of the scientific community is on large outlet glaciers draining the Antarctic and Greenland ice sheets (e.g. Rignot and others, 2014; Murray and others, 2015; Ryan and others, 2015), whereas smaller glaciers have been studied less. One reason for this is their relatively low impact on global-scale issues, like sea-level rise. Nevertheless, in some areas these smaller glaciers with relatively low ice flow velocities are most common and hence their calving is of great importance for regional-scale issues as glacial retreat, regional mass balance or fresh water input into local ecosystems. The South Shetland Islands are a perfect example of such a region. Due to the exposure to one of the most striking examples of air temperature rise in recent years (Vaughan and others, 2003; Turner and others, 2005; Kejna and others, 2013) large ice mass losses are observed in the area of northern Antarctic Peninsula

† Formerly at: Centro de Estudios Avanzados en Zonas Áridas, Raúl Bitrán s/n, La Serena, Chile.
(Cook and others, 2005; Hock and others, 2009). Nonetheless, given the observed climate change, the frontal retreat of the South Shetland Island glaciers is, mostly because of their topography, relatively small compared with other regions of the world (Osmanoglu and others, 2013, 2014). The South Shetlands mostly comprise small ice caps with few outlet glaciers, where the bulk of the ice cliffs terminate in the ocean on a high-water level mark, in the intertidal zone (Hughes and Nakagawa, 1989). This inhibits calving and limits oceanic influences, such as submarine melt or high-strain rates due to low basal pressure. Nevertheless, calving dominates ice mass loss of glaciers on the South Shetland Islands because of very low surface ablation rates (Navarro and others, 2013; Osmanoglu and others, 2014).

Despite recent advances in calving measurements stimulated by the development of new high-resolution surveying methods, for example terrestrial laser scanning (TLS) (e.g. Schwalbe and others, 2008; Pẹtlicki and others, 2015), Structure-from-Motion photogrammetry (e.g. Ryan and others, 2015) or terrestrial radar interferometry (e.g. Rolstad and Norland, 2009; Voytenko and others, 2015), there is still a lack of detailed quantitative observations of single calving events (Chapuis and Tetzlaff, 2014). Other techniques for example, visual observations (e.g. Chapuis and Tetzlaff, 2014), indirect methods like underwater accoustics (e.g. Glowacki and others, 2015) and seismic observations (e.g. O'Neel and others, 2010), lack sufficient precision to quantify ice volume loss during calving events. On the other hand, the classical remote sensing methods like repeat satellite imagery analysis or airborne photogrammetry have limited temporal resolution and therefore are best suited 
for tracking of particularly large calving events (e.g. Joughin and MacAyeal, 2005). Moreover, they are often restricted to measuring aerial changes and thus need to be parameterized with other methods to yield volume estimates.

TLS is now widely recognized as a precise, rapid and extremely useful method of surveying snow cover (e.g. Prokop, 2008; Egli and others, 2012; Deems and others, 2013; Hartzell and others, 2015) and glacial dynamics (e.g. Schwalbe and others, 2008; Petlicki and others, 2015). Despite the high cost of TLS relative to other techniques like Structure-from-Motion photogrammetry (Westoby and others, 2012), its high-spatial resolution and precision remains unparalleled (Passalacqua and others, 2015).

In recent years calving models have undergone a major change towards better description of the processes involved, from bulk models forced by an independent environmental variable like height-above-buoyancy (e.g. Vieli and others, 2002), through the crevasse depth criterion of Benn and others (2007a) implemented in several cases (Amundson and Truffer, 2010; Nick and others, 2010; Otero and others, 2010), to most recent models that account for damage mechanics (Krug and others, 2014) and are able to reproduce the crevassing of the terminal part of tidewater glaciers as well as the time and size distribution of individual events ( ström and others, 2013, 2014). The most recent and sophisticated models require much more precise calving size distribution data to validation purposes, but such data are scarce (Åström and others, 2014; Chapuis and Tetzlaff, 2014). The main goal of this work is to provide a detailed catalogue of the size distribution of calving events on Fuerza Aérea Glacier together with a methodology that allows for precise quantitative monitoring of calving.

\section{STUDY AREA}

Greenwich Island is located in the South Shetland Islands, Antarctica, a global 'hot-spot' of climate change, where a significant warming has been observed since the 1950s with a positive air temperature trend of $0.3^{\circ} \mathrm{C}(10 \mathrm{a})^{-1}$ (Vaughan and others, 2003). It is one of the 11 major islands of the archipelago with a surface area of $142 \mathrm{~km}^{2}$. Despite being located in the centre of the archipelago it has not drawn much attention from the physical sciences, except only a few glaciological, geomorphological or oceanographical studies (e.g. Arcos and Salamanca, 1980; Azhar and Santana, 2007; Santana and Dumont, 2007). Much more attention has been given to the neighbouring Livingston Island (e.g. Otero and others, 2010; Navarro and others, 2013; Osmanoglu and others, 2014) and particulary to the largest island of the archipelago, King George Island, where the surface mass balance (e.g. Knap and others, 1996; Braun and Hock, 2004; Sobota and others, 2015) and ice dynamics (e.g. Simoes and others, 1999; Rückamp and others, 2010, 2011; Osmanoglu and others, 2013; Sobota and others, 2015) have been investigated in detail. Although the Greenwich Island ice cap is part of the Antarctic periphery inventory (Bliss and others, 2013), its actual calving flux remains unknown.

Fuerza Aérea Glacier (Fig. 1) is one of the outlet glaciers of the Greenwich Island ice cap. It is located in the eastern part of Greenwich Island, has a width of $\sim 4.5 \mathrm{~km}$, length of $2 \mathrm{~km}$ and area of $7.26 \mathrm{~km}^{2}$ (WGMS, 1989). The glacier flows from the northwest slopes of the Breznik Heights into the eastern

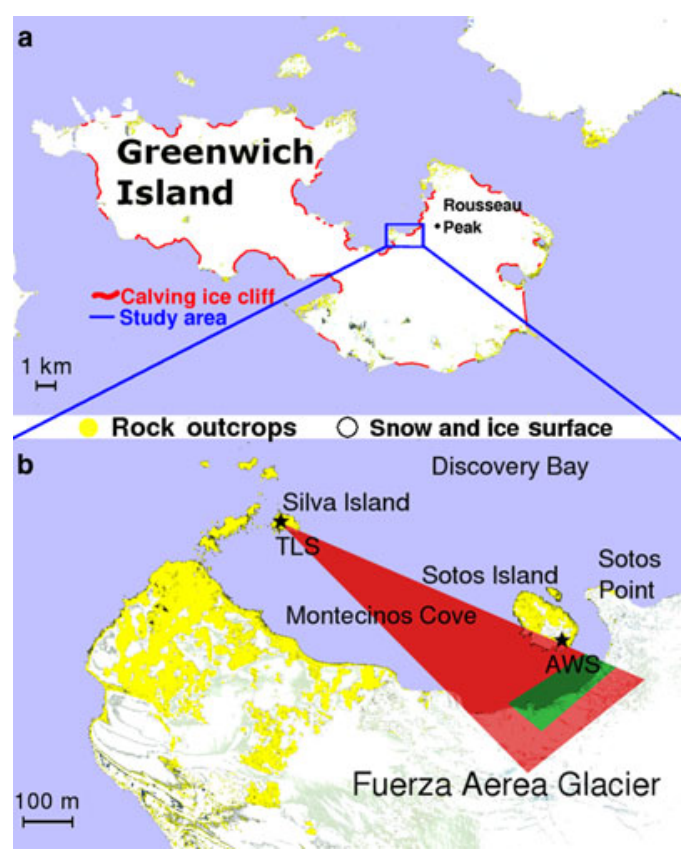

Fig. 1. Location of the study site: (a) Greenwich Island, (b) Surroundings of Fuerza Aérea Glacier showing the imposed scanned area (red), the investigated part of the ice cliff (green), TLS and AWS

coast of Discovery Bay. Fuerza Aérea Glacier is typical of outlet glaciers found on South Shetland Islands; it has relatively low calving rate, high crevassing in the terminal part due to a steep slope next to the front, and a terminus partly grounded at the high-water mark (with bedrock at the terminus submerged during high tides and exposed at low tides).

\section{DATA AND METHODS}

Results from TLS surveys and continuous video recording have been combined to assess volume changes of the active ice cliff of Fuerza Aérea Glacier. TLS was used to measure the volumes of individual calving events by differentiating subsequent point clouds, whereas the video provided continuous recordings of calving activity that were used to map the calved ice area. Because the front is grounded in very shallow water we assume the underwater calving on Fuerza Aérea Glacier is neglible. Therefore, the calved ice area is assumed to be equal to the area of the scar produced by calving on the subaerial part of the ice cliff. An empirical calved ice area/volume relationship was used to scale the areas derived by video observations to ice volumes using the TLS measurements as a reference. Finally, the record of calved ice volume was compared with potential environmental drivers of calving.

\subsection{Video monitoring}

A Mobotix MX-M24-M video camera with a $32 \mathrm{~mm}$ lens was installed on Sotos Island at the automatic weather station (AWS) site located $120 \mathrm{~m}$ from Fuerza Aérea Glacier (Fig. 1), overlooking the active ice cliff. Between 21 January and 04 February 2013 the camera continuously recorded a video of the ice cliff with a time resolution of 8 frames s$^{-1}$ and image resolution of $800 \times 600$ pixels. Calving events were tracked by visual inspection of the 
video frames immediately before and after each calving event. Areas of calved ice were mapped manually with Quantum GIS software (Fig. 2) and the associated polygons were exported to a shapefile. Polygons areas were expressed in pixels in a local coordinate system. Next, they were georeferenced by projecting them onto TLS-derived point clouds of the ice cliff using easily discernible features, such as crevasses, as a reference.

\subsection{Terrestrial laser scanning}

Surveys were made with Optech ILRIS-LR terrestrial laser scanner, a state-of-the-art instrument dedicated to topographic measurements of snow and ice surfaces. It has a wavelength of $1064 \mathrm{~nm}$ and a nominal operating range of 3000 $\mathrm{m}$; however, low reflection from clean ice limited range to $1000 \mathrm{~m}$ (Pẹtlicki and others, 2015). The scanner was placed on Silva Island (Fig. 1) at a distance of $\sim 800 \mathrm{~m}$ from the active ice cliff, which is in Montecinos Cove. The investigated part of the ice cliff is located south of Rousseau Peak next to Sotos Point and the neighbouring unnamed island, herein referred to as Sotos Island.

The sampling rate of the Optech ILRIS-LR is $30 \mathrm{kHz}$, hence 30000 points $\mathrm{s}^{-1}$ are acquired. However, the instrument was running in the field only for short periods, when meteorological conditions were suitable (no fog, precipitation or strong winds that could affect the measurements) and the sea conditions allowed reaching Silva Island from Arturo Prat Station. Therefore, throughout the observation period of $14 \mathrm{~d}$ (21 January-04 February 2013) only 6 TLS measurements were taken on 21, 25, 31 January and 1, 2 and 4 February 2013. Water vapour decreases the operating range and the quality of the return signal of the laser scanner and hence measurements cannot be made in poor visibility.

The measurement itself normally took a few hours, as a larger portion of the Montecinos Cove, than only the investigated part of the ice cliff, was scanned (Fig. 1), in order to capture ice-free areas that could be used for the point cloud alignment into a common reference frame.

The raw data stored in the scanner constitute of points in polar coordinates (azimuth angle, elevation angle, range from the scanner centre), together with their associated intensity of reflection and shot flags. Thus, the file can be regarded as a raw point cloud in polar coordinate system. Pre-processing was performed in Optech ILRIS Parser software and involved (1) trimming the point cloud, (2) applying the atmospheric correction for range, (3) change of polar coordinate system to Cartesian and (4) exporting the resulting point cloud to PTX format, Leica exchange format. The atmospheric correction applied was linear in range and accounted for air humidity, pressure and temperature.

Next, the point clouds were imported into the Cloud Compare software and georeferenced using four ground control points located on stable bedrock (Silva and Sotos Islands, Ferrer Point) in the vicinity of the glacier. Point clouds were then aligned using exposed bedrock on the islands and next to the ice front. The associated 3-D error, calculated as a RMS deviation between the point clouds, varies between 7 and $19 \mathrm{~cm}$.

The displacements between the point clouds were calculated along the flow direction. Ice advection displacements were low compared with the lengths of the calved ice blocks, thus an increase in distance from the scanner to the ice cliff was associated with calving, whereas a decrease was associated with ice front advance. Regions that did not experience calving in successive point clouds were used to calculate ice advection; ice velocities were assumed constant over the entire ice cliff apart from nine non-overlaying calving events that were used for area/volume scaling; for these local ice advection was calculated from their respective histograms of displacements. Ice advection was calculated from the maximum positive peak in the histograms of displacement along the width of the terminus. The length of calved ice blocks was obtained by adding the calculated local ice advection value to the increase in distance measured between the scanner and the ice cliff.

\subsection{Area/volume scaling}

The relation between area and volume is assumed to be a polynomial of degree $3 / 2$, i.e. the length of the calved ice block is proportional to the square root of its area. In other words, the length $x$ is linearly proportional to the other two dimensions of the ice block, its width and height. This assumption can be supported by previous observations of the similarity between frequency distributions of iceberg widths and freeboards (Dowdeswell and Forsberg, 1992). The resulting relation is:

$$
V_{\mathrm{c}}=\int_{x_{0}}^{x_{1}} A(x) \mathrm{d} x \approx C A_{\mathrm{C}}^{3 / 2}
$$

where $V_{\mathrm{c}}$ is the volume of the calved ice block, $x_{0}, x_{1}$ are the positions of the ice cliff before and after calving, respectively, $C$ is a constant scaling factor, $A(x)$ is the sectional area of the

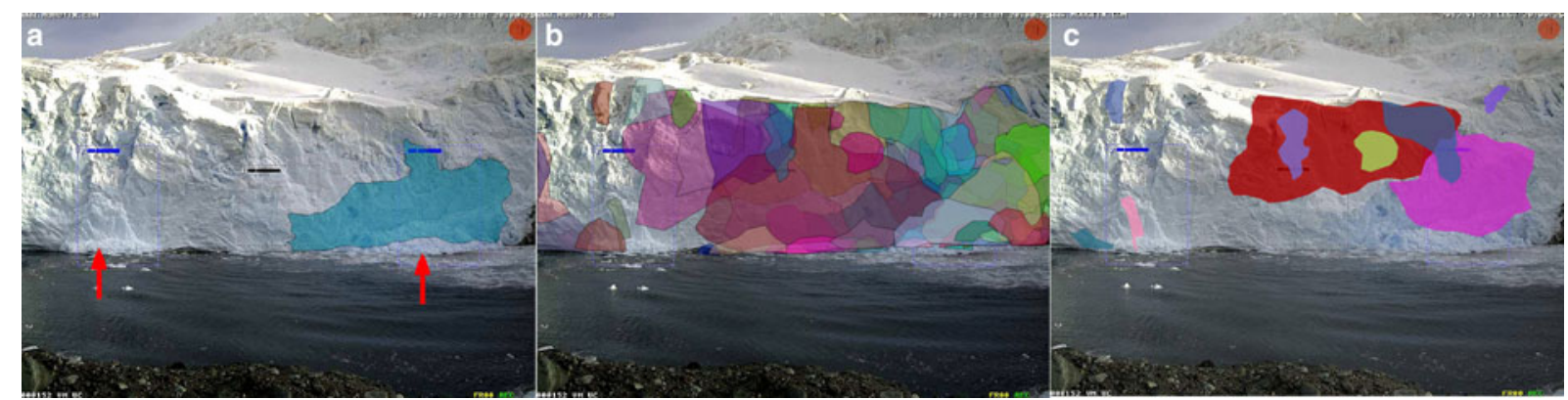

Fig. 2. Calving events of Fuerza Aérea Glacier identified on video recording. (a) An example from 21 January 2013. (b) Complete record for 21 January-04 February 2013. (c) Nine events that did not occur from the same space on the calving cliff as others during the time interval between TLS measurements. Areas of different color are areas of the cliff that failed, red arrows indicate fallen ice accumulated in shallow water. 
calved block a distance $x$ back into the block, and $A_{c}$ is the overall cross-sectional area of the calved ice block. Although such parameterization is very simple it still retains some physical relevance - the overall shape of the calved ice is assumed to be near constant.

The calving event polygons obtained from video monitoring were projected onto the respective georeferenced ice cliff point clouds. This allowed a calculation of the area of the calved ice block and its corresponding volume by differentiating subsequent point clouds before and after the event. The length of the calved ice block was calculated as the sum of ice advection and the difference between a pre-calving and post-calving measurement of a distance to the point on the cliff. Then, the volume of the calved ice block was obtained by multiplying these lengths with the corresponding areas subtended by the measurement and summing these for all points $y, z$ within a scar left by the calved block delineated by the respective polygon:

$$
V_{\mathrm{c}}=\sum_{(y, z) \in A_{c}} A(y, z)\left(\Delta x_{y, z}+v \Delta t\right)
$$

where $V_{\mathrm{c}}$ is the volume of the calved ice block, $A_{\mathrm{c}}$ is the area of a scar left by the calved block, $(y, z)$ is the position of the point within $A_{c}, A(y, z)$ is the area corresponding to the point $(y, z), \Delta x_{y, z}$ is the change in distance at point $(y, z)$ and $v \Delta t$ is the ice advection.

\subsection{AWS and water properties measurements}

An AWS was installed on Sotos Island, $120 \mathrm{~m}$ from the investigated ice cliff. It recorded air temperature, relative humidity, atmospheric pressure and global radiation in $10 \mathrm{~s}$ intervals.

A Schlumberger MiniDiver was installed by the rocky coast of Silva Island (Fig. 1). The sensor continuously measured water temperature and pressure during the duration of the study. The water pressure was then corrected for atmospheric pressure changes using data collected by the AWS on Sotos Island and transformed to water height.

\section{RESULTS}

\subsection{Video monitoring}

Visual inspection of the video recording resulted in the detection and mapping of 64 calving events with areas ranging from 190 to 50729 pixels. The majority of the calving events were small, with a mean area of 6657 pixels and median of 2236 pixels. There were only ten calving events with an area $>10000$ pixels (Fig. 3). Throughout the observation period there was only one full size breakoff of almost the entire cliff on 24 January (16:32 h), with a calved area of 50729 pixels. The left side of the cliff has experienced

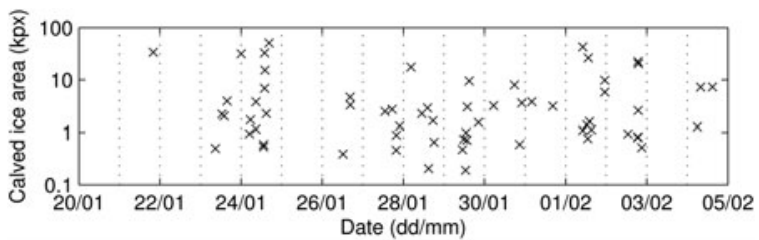

Fig. 3. Area of calving events of Fuerza Aérea Glacier between 21 January and 04 February 2013 recorded by video camera. less calving, with some regions showing no calving activity during the whole recording period (Fig. 2b).

In several instances the calved ice remained grounded in waters next to the cliff for several days before being melted and removed by tidal action, indicating a shallow depth along the submerged ice front. The glacier calved both day and night, with the most activity seen on 24, 28-29 January and 01-02 February while on 22, 25 January and 03 February no calving was recorded (Fig. 3 ).

In total, nine calving events that did not overlap one another on the ice cliff during the time interval between TLS measurements were identified and later used for the area/volume scaling.

\subsection{Terrestrial laser scanning}

Ice flow velocity at the terminus was calculated as the value corresponding to the peak in the positive part of the histogram of front position changes, and the corresponding error was assumed to be equal to the standard deviation of this peak (Fig. 4; Table 1). The ice flow velocity varied $\sim 0.3 \mathrm{~m}$ $\mathrm{d}^{-1}$, ranging from $0.21 \pm 0.17 \mathrm{~m} \mathrm{~d}^{-1}$ over the period 01-02 February to $0.36 \pm 0.19 \mathrm{~m} \mathrm{~d}^{-1}$ over the period 31 January01 February (Fig. 4; Table 1). As shown on the histograms, the peaks become wider when the time frame between the measurements increases (Figs 4a, b, e), whereas they are very narrow when the surveys are conducted at intervals of
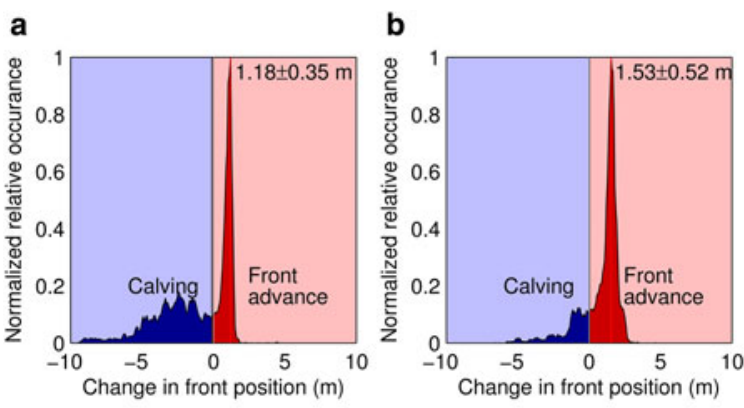

C

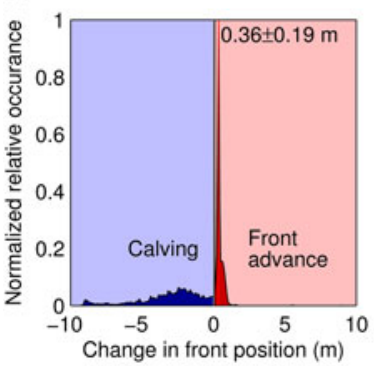

d
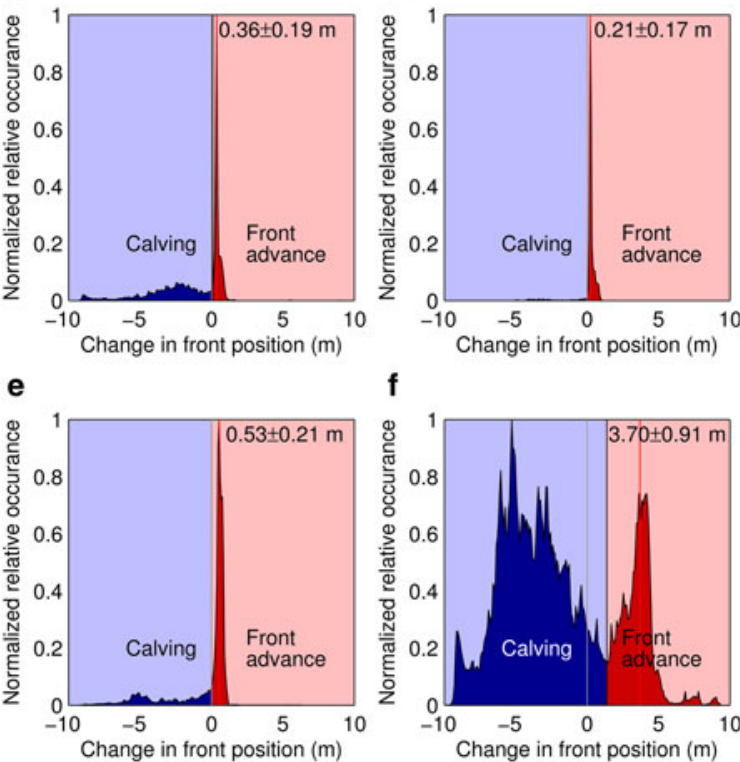

Fig. 4. Histograms of the changes of ice front position of Fuerza Aérea Glacier between 21 January and 04 February 2013. (a) 2125 January, (b) 25-31 January, (c) 31 January-01 February, (d) 0102 February, (e) 02-04 February, (f) 21 January-04 February. 
Table 1. Ice front position changes, ice flow velocities and calving rate of Fuerza Aérea Glacier measured with TLS over the period 21 January - 04 February 2013

\begin{tabular}{|c|c|c|c|c|c|c|}
\hline $\begin{array}{l}\text { Period } \\
2013\end{array}$ & $\begin{array}{c}\text { Front position } \\
\text { change } \\
M\end{array}$ & $\begin{array}{c}\text { Front position } \\
\text { change rate } \\
\qquad \mathrm{m} \mathrm{d}^{-1}\end{array}$ & $\begin{array}{c}\text { Ice flow } \\
\text { displacement } \\
M\end{array}$ & $\begin{array}{l}\text { Ice flow } \\
\text { velocity } \\
\mathrm{m} \mathrm{d}^{-1}\end{array}$ & $\begin{array}{l}\text { Calving } \\
\text { M }\end{array}$ & $\begin{array}{l}\text { Calving } \\
\text { rate } \\
\mathrm{m} \mathrm{d}^{-1}\end{array}$ \\
\hline 21 January-25 January & $-1.13 \pm 0.25$ & $-0.28 \pm 0.06$ & $1.18 \pm 0.35$ & $0.29 \pm 0.09$ & $2.31 \pm 0.43$ & $0.58 \pm 0.11$ \\
\hline 25 January-31 January & $0.83 \pm 0.25$ & $0.14 \pm 0.04$ & $1.53 \pm 0.52$ & $0.26 \pm 0.09$ & $0.70 \pm 0.58$ & $0.12 \pm 0.10$ \\
\hline 31 January-01 February & $-1.38 \pm 0.17$ & $-1.38 \pm 0.17$ & $0.36 \pm 0.19$ & $0.36 \pm 0.19$ & $1.74 \pm 0.25$ & $1.74 \pm 0.25$ \\
\hline 01 February-02 February & $0.11 \pm 0.15$ & $0.11 \pm 0.15$ & $0.21 \pm 0.17$ & $0.21 \pm 0.17$ & $0.10 \pm 0.23$ & $0.10 \pm 0.23$ \\
\hline 02 January-04 February & $-0.44 \pm 0.18$ & $-0.22 \pm 0.09$ & $0.53 \pm 0.21$ & $0.26 \pm 0.11$ & $0.96 \pm 0.28$ & $0.48 \pm 0.14$ \\
\hline 21 January-04 February & $-2.07 \pm 0.19$ & $-0.15 \pm 0.01$ & $3.70 \pm 0.91$ & $0.26 \pm 0.07$ & $5.77 \pm 0.98$ & $0.41 \pm 0.07$ \\
\hline
\end{tabular}

only $1 \mathrm{~d}$ (Figs 4c, d). Calving, indicated by the front retreat, shows a very dispersed histogram, which suggests large variability in the length of calved ice blocks (Figs 4a-c). Even though the calved ice block may have variable length (it does not need to be a prismoid), its mean length is assumed to remain proportional to its mean width and mean height.

Figure 5 shows the changes in ice front position as measured by the point cloud differentiation, so that a positive change corresponds to frontal advance and negative change to frontal retreat. The ice front position was changing throughout the study period, with a pronounced advance on the left side of the cliff and a retreat associated with calving over the rest of the cliff (Fig. 5). The ice front advance in areas where no calving occurred between measurements is presented in Figure 6. Then, ice front retreat due to calving (Fig. 7) was calculated by subtracting the mean ice flow velocity estimated using the histograms (Fig. 4) from the respective ice front position change map (Fig. 5).

The position changes were relatively small, ranging from -9 to $+2 \mathrm{~m}$ over 2 weeks, resulting in an overall mean front retreat of $2.07 \pm 0.19 \mathrm{~m}$ (Table 1). Much larger values were recorded where the fallen ice accumulated in shallow water; this is clearly seen in Figures $5 \mathrm{e}, \mathrm{f}$. At the beginning of the observations (21-25 January), the negative ice position changes were concentrated in the centre of the ice cliff (Fig. 5a), reaching values of $-9 \mathrm{~m}$, whereas the lateral parts advanced (Fig. 6a). The lengths of the calved ice, normal to the ice front, were $\sim 3-6 \mathrm{~m}$ (Fig. 7a). During the next observation period (25-31 January, Figs 5b, 6b) almost the entire ice cliff advanced, with a mean position change of $0.83 \pm 0.25 \mathrm{~m}$ (Table 1). There was some calving activity in the right part of the cliff (Fig. 7b). The next day (31 January-01 February) extensive calving activity was observed (Fig. 7c), resulting in substantial retreat $(1.38 \pm 0.17 \mathrm{~m}$; Table 1 ; Fig. $5 \mathrm{c})$ despite the fact that the maximum ice flow velocity of $0.36 \pm 0.19$ $\mathrm{m} \mathrm{d}^{-1}$ occurred on this day (Table 1). Following that, on 01-02 February, almost no calving occured (Fig. 7d) and the entire ice front advanced (Fig. $6 \mathrm{~d}$ ), resulting in a positive mean front position change of $0.11 \pm 0.15 \mathrm{~m}$ (Table 1; Fig. $5 d$ ). During the last period of measurements, calving took place only in the upper right corner of the ice cliff (Fig. 7e). As mentioned, some of the fallen ice could be clearly identified (Fig. 5e) grounded in shallow water. The overall change in ice front position is presented in Figure $5 f$, where two distinct features can be distinguished: an advance on the left side of the cliff due to ice flow advection undisturbed by calving (Fig. 6f), and large, homogeneous retreat elsewhere caused by several calving events of different sizes (Fig. 7f). There are some discrepancies between Figures $6 f$ and $2 b$, concerning areas not affected by calving, especially in the left side of the cliff. It seems that the calved ice block that can be seen in the left edge of the cliff was of small length

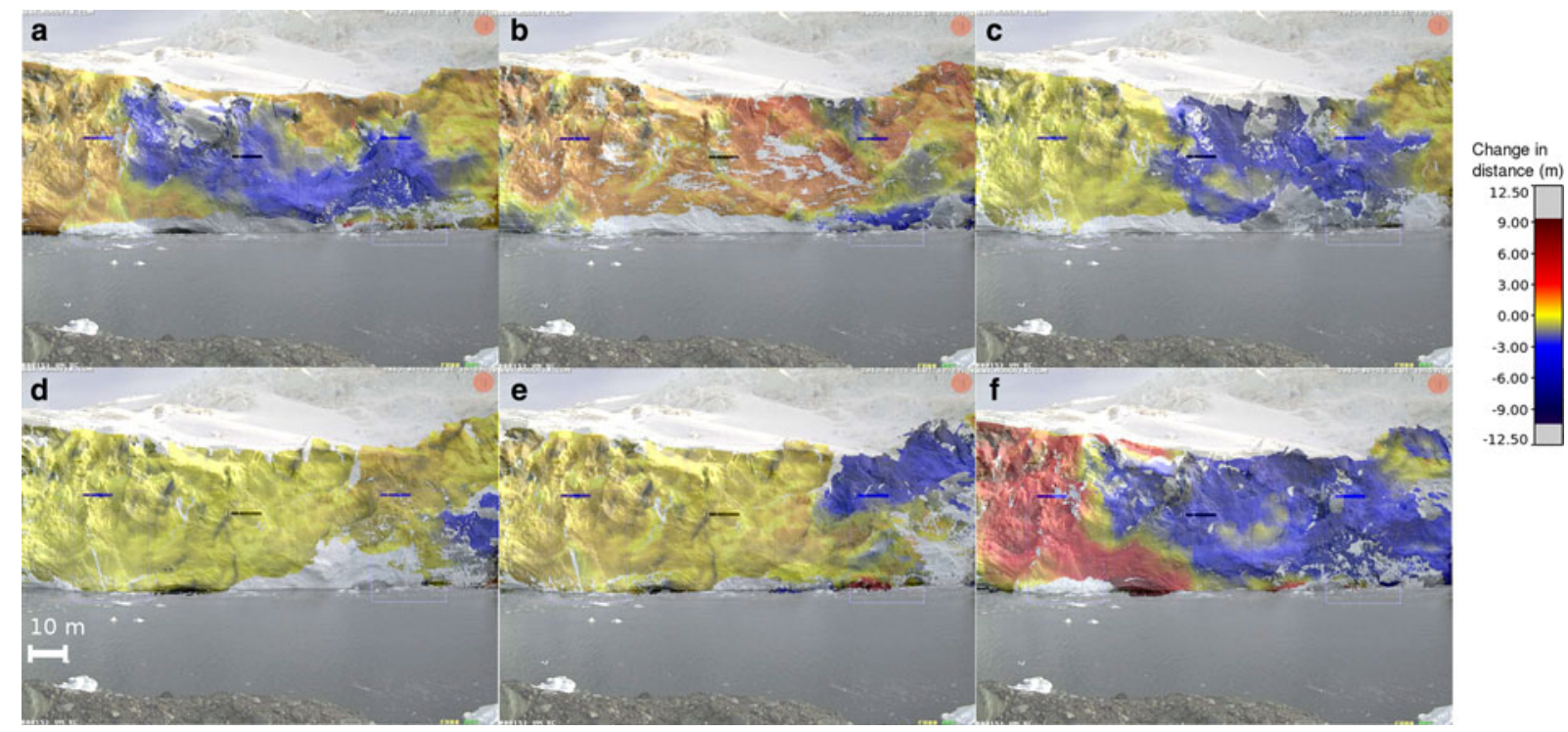

Fig. 5. Changes in the ice front position of Fuerza Aérea Glacier measured with TLS between 21 January and 04 February 2013. (a) 21-25 January, (b) 25-31 January, (c) 31 January-01 February, (d) 01-02 February, (e) 02-04 February, (f) 21 January-04 February. 

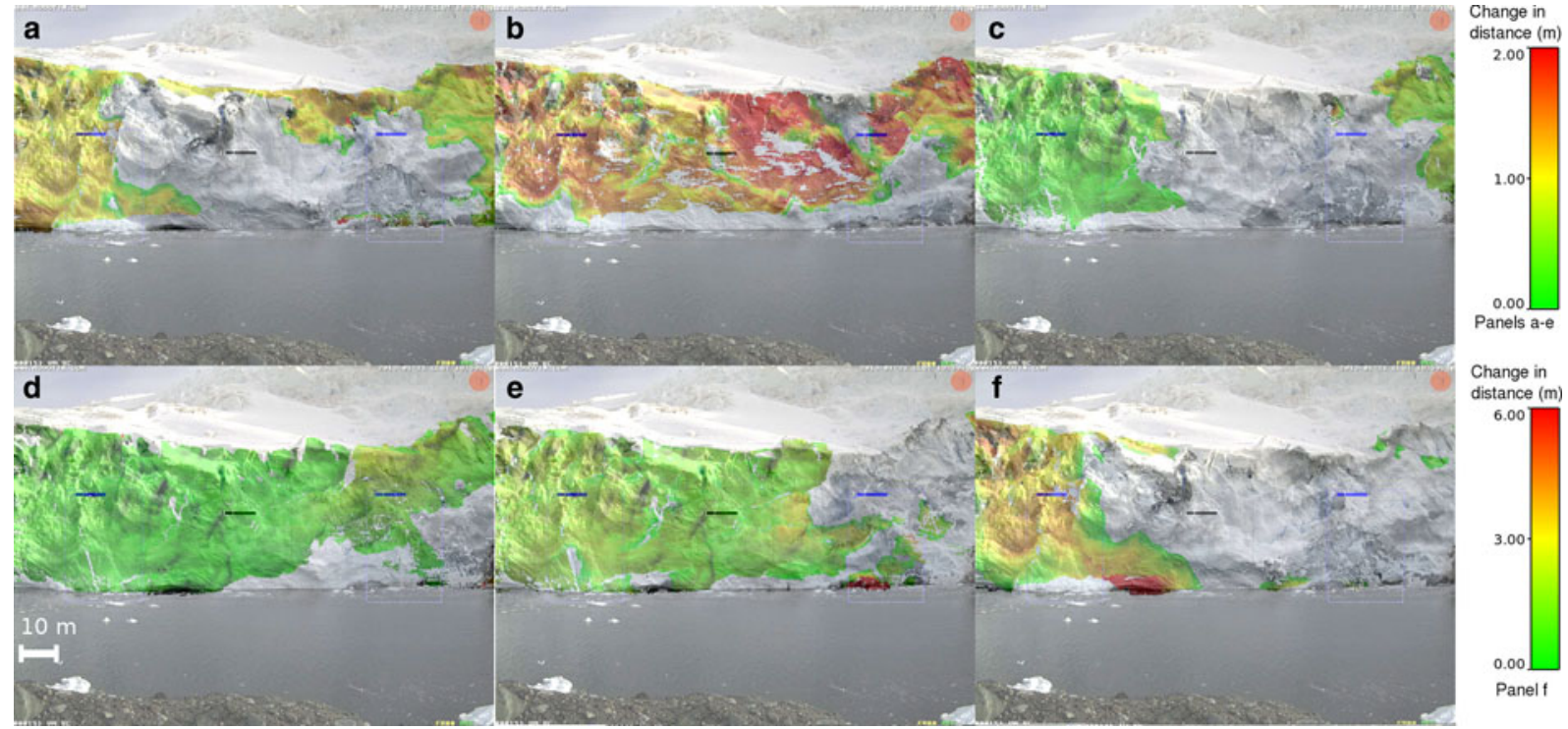

Fig. 6. Ice front advance of Fuerza Aérea Glacier in the areas where no calving occurred, measured with TLS between 21 January and 04 February 2013. (a) 21-25 January, (b) 25-31 January, (c) 31 January-01 February, (d) 01-02 February, (e) 02-04 February, (f) 21 January04 February. Note the different color scale on panel (f).

in comparison with the ice front advance over the entire investigated period and therefore was not detected. However, during a shorter observation period it was properly detected, as it can be seen in Figures $6 \mathrm{~b}$ and $7 \mathrm{~b}$.

Even though a clear linear relationship between the measured calving rate and the ice flow velocity at the terminus can be seen in Figure 8, the associated errors of both variables are high (Table 1 ) and the number of points used is low. Nonetheless, the correlation coefficient is high $\left(R^{2}=\right.$ 0.88 ) and there are no outliers, indicating a possible link between the ice flow velocity and calving rate.

\subsection{Area/volume scaling}

In total, nine non-overlapping calving events, spread over the entire ice cliff surface, were identified both in the video monitoring and the laser scans. They had a total volume of $9471 \mathrm{~m}^{3}$, ranging from 0.29 to $5821 \mathrm{~m}^{3}$ (Fig. 9; Table 2). Their area ranged from 961 to 42592 pixels as measured from the video recording and $1.53-1358 \mathrm{~m}^{2}$ as measured with TLS. A fit to these values (Eqn. (1); Figs 9a, d) was then applied. The volume measurement error was large, especially for smaller calving events (Table 2). The standard deviation of the residuals of fit and observed volumes was low (Figs 9c, d), which can be explained by the small number of large calving events having a large influence on the parameters of the fit. Thus, the error of the fit was set to equal the mean percentage measurement error of the three largest calving events, $16 \%$. Afterwards, this relationship was applied to the record of calving events from video monitoring (Fig. 3) resulting in a complete record of calved ice volume (Fig. 10).
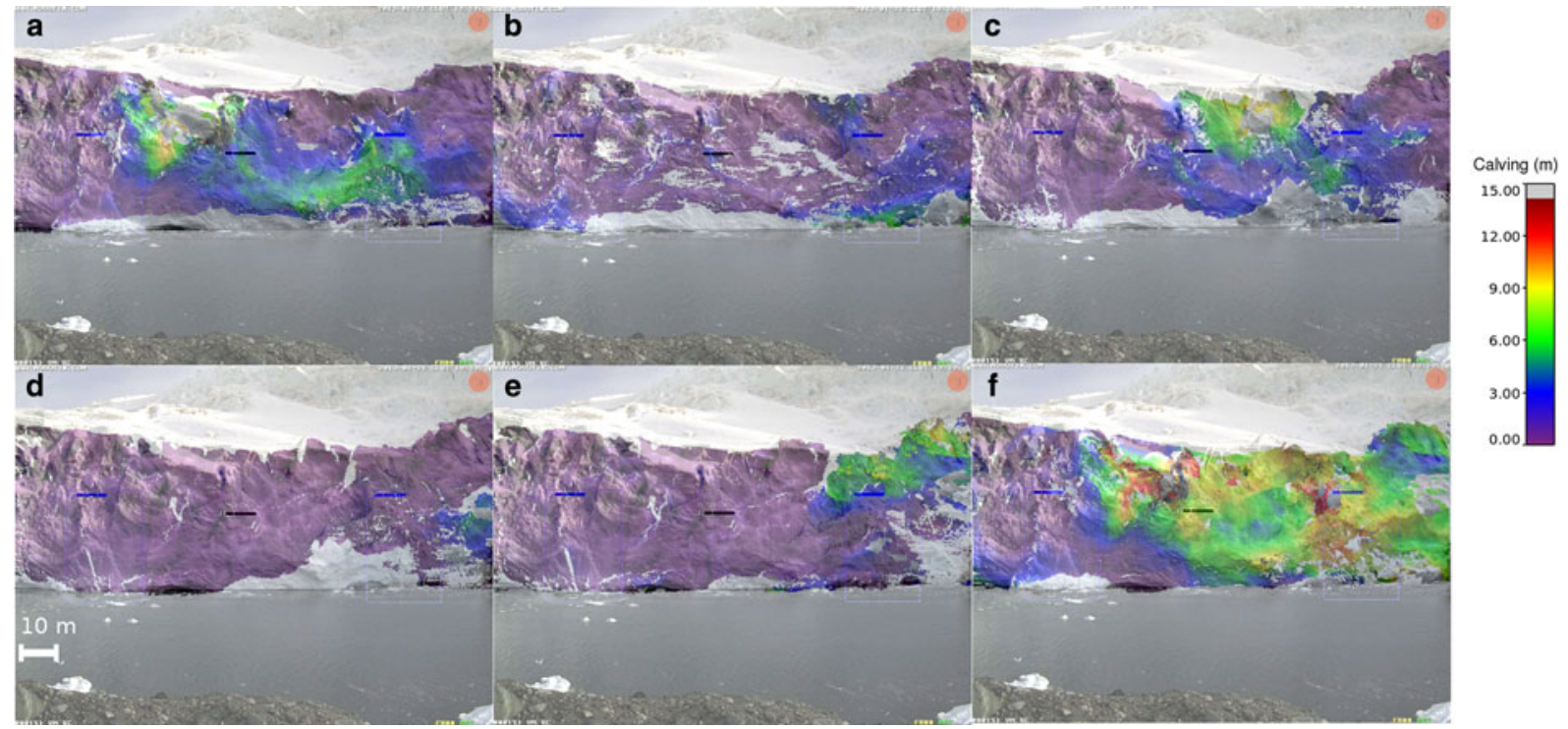

Fig. 7. Calving at the ice cliff of Fuerza Aérea Glacier between 21 January and 04 February 2013. (a) 21-25 January, (b) 25-31 January, (c) 31 January-01 February, (d) 01-02 February, (e) 02-04 February, (f) 21 January-04 February. 


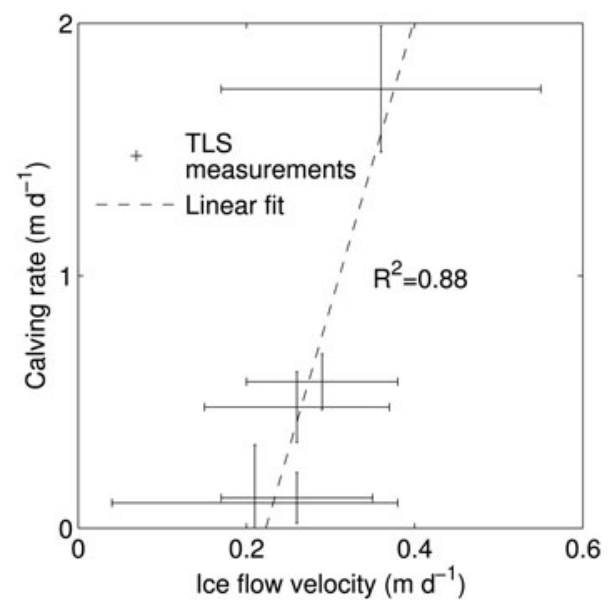

Fig. 8. Scatter plot of calving rate and ice flow velocity of Fuerza Aérea Glacier between 21 January and 04 February 2013.

The total volume of calving in the investigated period, obtained by summing all individual calving events, is thus estimated to be $40585 \pm 6494 \mathrm{~m}^{3}$ (Table 3). The direct estimate of calving from TLS results calculated as mean calving rate (Table 1) multiplied by the surface area of the cliff yields $38590 \pm 6554 \mathrm{~m}^{3}$ (Table 3).

\section{DISCUSSION}

Despite the advantages of the TLS over other surveying methods no detailed study of its application to measurements of calving intensity has so far been published (Chapuis and Tetzlaff, 2014; Pẹtlicki and others, 2015, provide further details). Though the use of TLS is severely limited by its
Table 2. Size of nine events that did not occur from the same space on the calving cliff as others during the time interval between TLS measurements. The volume error is calculated as combination of TLS measurement error (point cloud alignment) and ice advection estimation

\begin{tabular}{lcrrc}
\hline Date & Hour & Area pixels & $\begin{array}{c}\text { Area } \\
\mathrm{m}^{2}\end{array}$ & \multicolumn{1}{c}{$\begin{array}{c}\text { Volume } \\
\mathrm{m}^{3}\end{array}$} \\
\hline 28 January 2013 & $17: 33$ & 1652 & 51.38 & $47.34 \pm 26.72$ \\
30 January 2013 & $05: 25$ & 3196 & 98.62 & $81.11 \pm 51.29$ \\
30 January 2013 & $17: 43$ & 8002 & 311.54 & $552.53 \pm 162.00$ \\
30 January 2013 & $22: 05$ & 3599 & 126.80 & $132.90 \pm 67.20$ \\
01 February 2013 & $00: 10$ & 42592 & 1358.30 & $5820.97 \pm 488.99$ \\
01 February 2013 & $13: 21$ & 26290 & 836.89 & $2809.49 \pm 301.28$ \\
01 February 2013 & $15: 19$ & 1119 & 19.97 & $0.29 \pm 3.39$ \\
02 February 2013 & $12: 53$ & 931 & 36.06 & $8.77 \pm 6.13$ \\
04 February 2013 & $05: 56$ & 1273 & 34.12 & $17.48 \pm 7.16$ \\
\hline
\end{tabular}

vulnerability to meteorological conditions (especially in polar regions), it can be successfully combined with other methods, such as video monitoring, passive seismics or underwater acoustics, to provide a continuous record of calving volumes. The use of video recording is limited by the availability of sunlight and therefore is not suitable for year-round monitoring in polar regions. However, in such regions it is useful during the period of midnight sun when it can work for $24 \mathrm{~h} \mathrm{~d}^{-1}$. For this reason, passive seismics and underwater acoustics seem to be the best complementary methods for TLS for long-term monitoring as they are largely independent of light and weather conditions. Nonetheless, their low sensitivity to small volume calving (e.g. O'Neel and others, 2010; Bartholomaus and others, 2015; Glowacki and others, 2015) imposes a limit on their
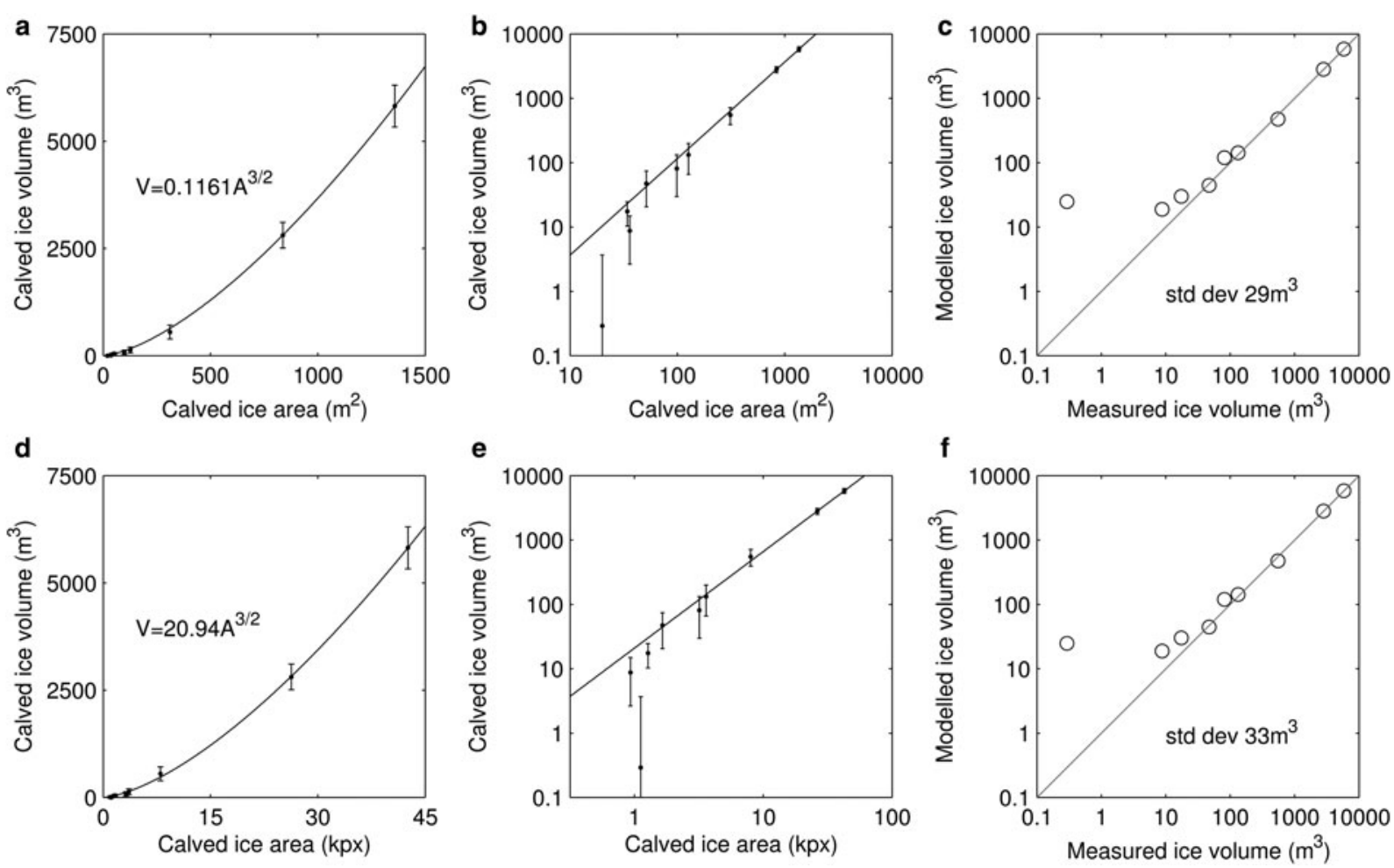

Fig. 9. Calving event area/volume scaling. (a)-(c) Area measured with TLS. (d)-(f) Area measured with video monitoring. (c), (f) Scatter plots of measured vs. modelled calving event volume. The error bars show the combined error of volume calculation due to TLS measurement error (point cloud alignment) and ice advection estimation. 

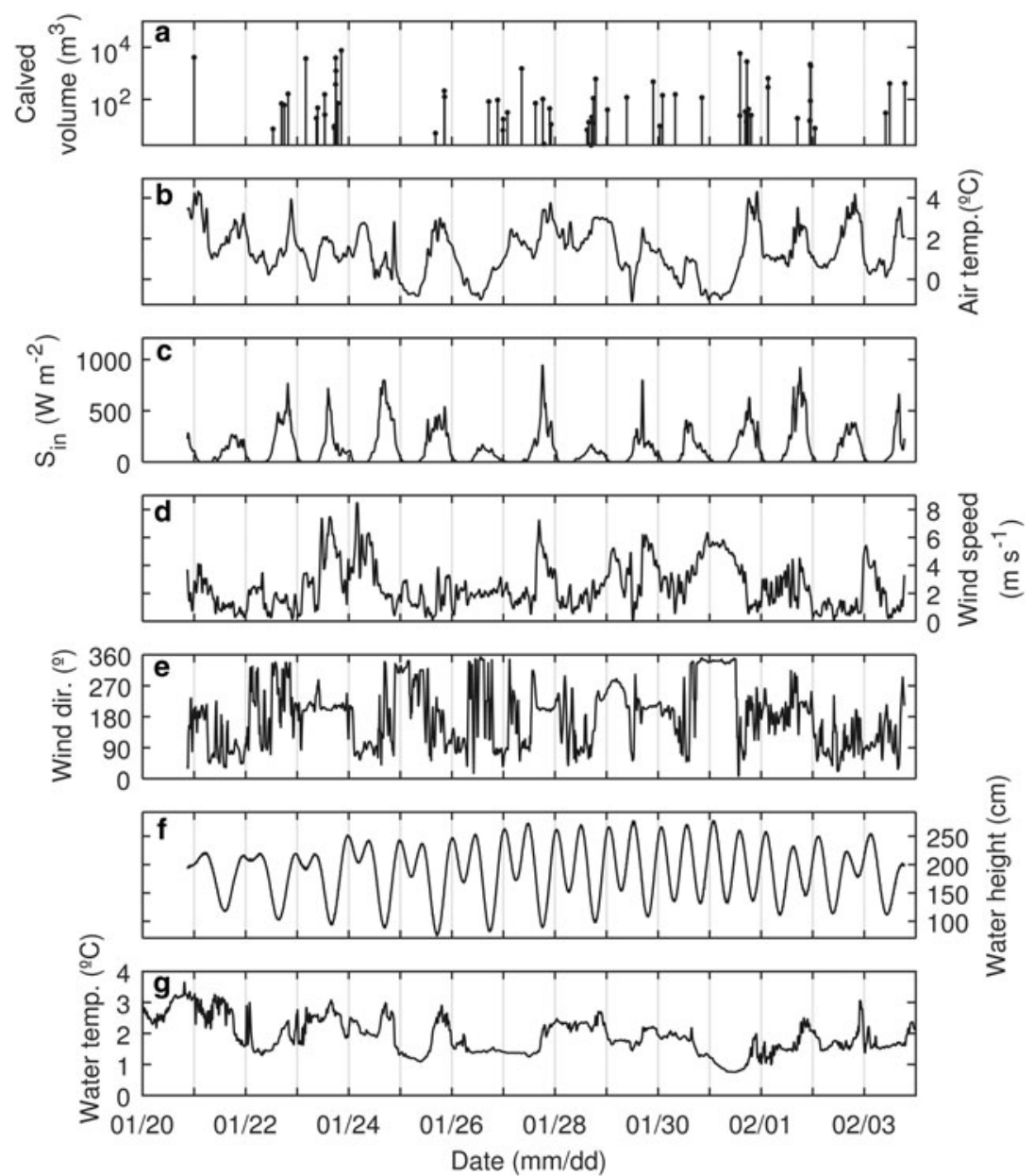

Fig. 10. Calving events and potential environmental drivers recorded during the study period. (a) Calving volume; (b) air temperature; (c) shortwave incoming radiation; (d) wind speed; (e) wind direction; ( $f$ ) water height; (g) water temperature.

Table 3. Calving of Fuerza Aérea Glacier over the period of 21 January - 04 February 2013

\begin{tabular}{lcc}
\hline Method & $\begin{array}{c}\text { Calving flux } \\
\mathrm{m}^{3} \mathrm{~d}^{-1}\end{array}$ & $\begin{array}{c}\text { Total calving } \\
\mathrm{m}^{3}\end{array}$ \\
\hline TLS & $2756 \pm 468$ & $38590 \pm 6554$ \\
Volume/area scaling & $2890 \pm 464$ & $40585 \pm 6494$ \\
\hline
\end{tabular}

applicability to smaller glaciers with low energy calving events. In such instances video recording proves to be a more useful method.

Another advantage of using a video camera over a timelapse camera is that the whole calving event is captured both with image and sound, allowing for more reliable recognition and mapping. A video record of calving gives insight into the fracture processes that can help classify mechanics (e.g. Bartholomaus and others, 2012; Glowacki and others, 2015). The automatic motion detection of the video camera was not a useful tool for calving detection, as the presence of sea birds, changing light conditions and wave action triggered the recording much more often than actual calving. It is worth noting that the calving events that occurred during twilight were identified with the audio recordings that accompanied the video.

A linear relationship between calving rate and ice flow velocity at the terminus was observed (Fig. 8). Similar relationships have been reported before for tidewater glaciers at seasonal to annual timescales (e.g. van der Veen, 1996), but were not observed at short timescales such as in this study (O'Neel and others, 2003). As opposed to the aforementioned studies, the front of Fuerza Aérea Glacier is grounded in very shallow water so that ice flow at the front will not be affected by tidal buoyancy changes. As calving could not be related to any of the potential environmental drivers but was found to be related to ice flow velocity, the ice flow variations themselves must arise from internal glacier processes.

\subsection{Probability distribution of calving events}

The observed cumulative distribution functions (cdf) of calving event size $\mu\left(\mathrm{m}^{3}\right)$ and inter-event interval $\tau$ (min) are shown in Figure 11. The observed distributions were modelled with four commonly used distributions for skewed positive data (power law, exponential, Weibull or 'stretched exponential' and log-normal) using the maximum likelihood method. The distributions are compared in Table 4 using the Akaike information criterion ( $\mathrm{AIC}=2 k-2 \ln L$, where $L$ is the maximum value of the likelihood function and $k$ the number of parameters for the distribution). The AIC rewards goodness of fit as assessed by the likelihood function but also penalizes an increase in the number of estimated parameters. A Monte-Carlo Kolmogorov-Smirnov (KS) goodness-of-fit test (Clauset and others, 2009) was also applied 

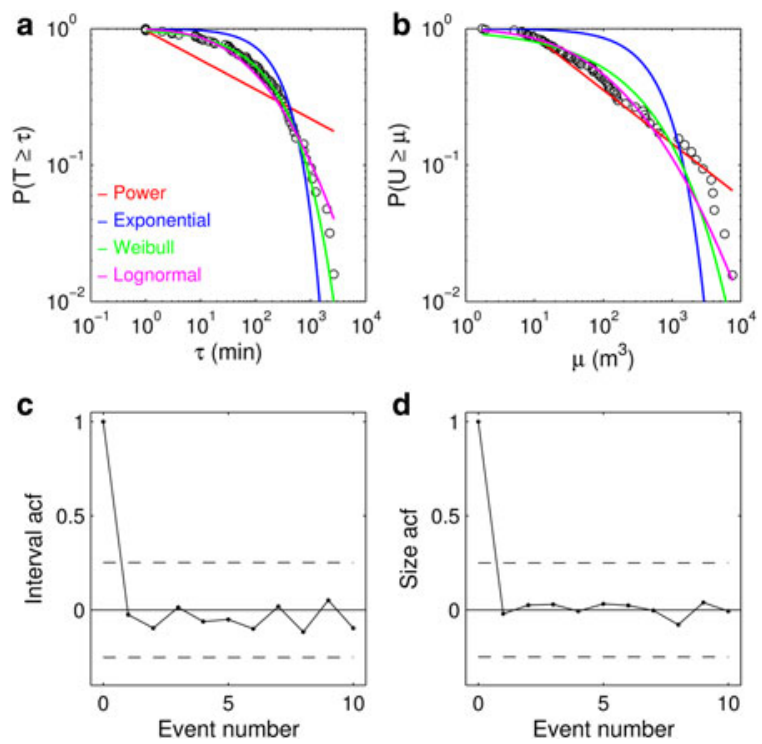

Fig. 11. Cumulative density function (cdf) and autocorrelation (acf) function of calving sizes $\mu\left(\mathrm{m}^{3}\right)$ and interval times $\tau$ (min). (a), (b) Observed (circles) and fit (color lines) cdfs for interval times and calving volumes, respectively. (c) Interval acf vs event number. (d) Calving size acf vs event number. Dashed lines in panels (c) and (d) show 95\% significance levels.

Table 4. Akaike information criterion (AIC) and $p$-value of the Kolmogorov-Smirnov (KS) statistic for the theoretical distributions fitted to observed size and inter-event interval data of calving

\begin{tabular}{lccccc}
\hline \multirow{2}{*}{ Distribution } & \multicolumn{2}{c}{ Size } & & \multicolumn{2}{c}{ Interval } \\
\cline { 2 - 3 } \cline { 5 - 6 } & AIC & $\begin{array}{c}\text { KS } \\
p \text {-value }\end{array}$ & & AIC & $\begin{array}{c}\text { KS } \\
p \text {-value }\end{array}$ \\
\hline Power & 739 & 0.00 & & 865 & 0.00 \\
Exponential & 956 & 0.00 & & 853 & 0.00 \\
Weibull & 841 & 0.00 & & 824 & 0.99 \\
Lognormal & 857 & 0.17 & & 820 & 0.67
\end{tabular}

A $p$-value $<0.10$ rejects the null hypothesis that the observed distribution follows a given theoretical distribution.

to test the null hypothesis that the observed data follow a hypothesized distribution. Briefly, for each distribution type, 5000 random datasets are generated using the distribution parameters fit to the observed data. Each synthetic dataset is then fit with its own distribution model and the KS statistic is calculated. The $p$-value corresponds to the fraction of the number of times that the resulting statistic is larger than the value for the empirical data. Following Clauset and others (2009), a $p$-value $<0.10$ is used to reject the null hypothesis.

The simplest model to consider for discrete events such as calving events would be a marked Poisson point process, which implies that calving events occur randomly in time. In this case the inter-event time interval can be shown to be exponentially distributed and independent in time (e.g. Lowen and Teich, 2005). Neither the power cdf, which has been reported for observed and simulated calving events (Åström and others, 2014; Chapuis and Tetzlaff, 2014), nor the exponential cdf fit the interval data well (Fig. 11a) and both also fail the $K S$ test, while the Weibull and log-normal distributions both fit the data better and pass the hypothesis test (Table 4). The assumption of time independence on the other hand is confirmed by the autocorrelation function (acf) plot, which shows insignificant lagged correlations (Fig. 11c). Based on these observations the occurrence of calving events appears to follow neither a simple Poisson process nor a fractal point process with power- law distributed interval times (e.g Lowen and Teich, 2005). The calving event size distribution (Fig. 11b) is not well fit by any of the distributions considered; only the lognormal distribution passes the hypothesis tests, but with a rather low $p$-value (Table 4). However, the power-law distribution fits the data well until a cut off near $1.5 \times 10 \mathrm{~m}^{3}$ after which the calving probability decreases. The acf function of event sizes shows no memory in the calving process (Fig. 11c).

Åström and others (2014) recently showed that modelled and observed calving fragment size and inter-event interval distributions tend to follow power laws, suggesting that calving exhibits self-organized criticality (SOC; e.g. Lowen and Teich, 2005). SOC systems have a sub-critical regime distinguished by infrequent and small avalanches, allowing instability to build up with time and a super-critical regime distinguished by large avalanches and widespread relaxation of the conditions (stresses) responsible for the instability. They spontaneously self-organize towards a stable 'critical point' between these two unstable regimes, and close to this critical point (the 'critical region'), the system begins to exhibit scale invariance (Åström and others, 2014). They noted that grounded tidewater glaciers in Svalbard and Alaska were best fit by a power law with a cut off at $\sim 10^{4}$ $\mathrm{m}$, which reflects how calving is limited by the dimensions of the terminus. While Åström and others (2014) present compelling evidence in support of calving behaving as a SOC system, at least one glacier studied by these authors did not exhibit a power-law inter-event interval distribution (Yahtse Glacier; Åström and others, 2014, their Supplementary Fig. 3). Chapuis and Tetzlaff (2014) also showed that interevent interval distributions are broad but have a less pronounced tail than power laws. Our results are in line with those of Chapuis and Tetzlaff (2014): while our event size distribution appears to follow a power law with an exponential cut off near $1.5 \times 10 \mathrm{~m}^{3}$, the inter-event interval distribution does not follow an exponential model (Poisson process), and also has a less pronounced tail than the power law implied by SOC systems.

\subsection{Environmental forcing of calving events}

Calving events are represented in Figure 10 along with the different environmental variables recorded during the study period. Elevated temperature and incoming solar radiation could in theory increase the probability of calving, through increased surface melting and resulting infiltration of meltwater in crevasses (Benn and others, 2007b). Using the wind speed as a proxy of ocean wave intensity, it might be expected that stronger onshore winds (north to northeasterly in this case) combined with elevated ocean water temperature will favor calving by thermo-erosional undercutting of the ice cliff at the ocean waterline. This has been shown to be an important process for tidewater glaciers (Pẹtlicki and others, 2015). Tidal variations affect buoyancy forces at the glacier front. Decreasing and low tides have been shown to increase ice motion at a glacier front (Sugiyama and others, 2015) and to increase calving fluxes (Bartholomaus and others, 2015). However, no simple relationship appears to 

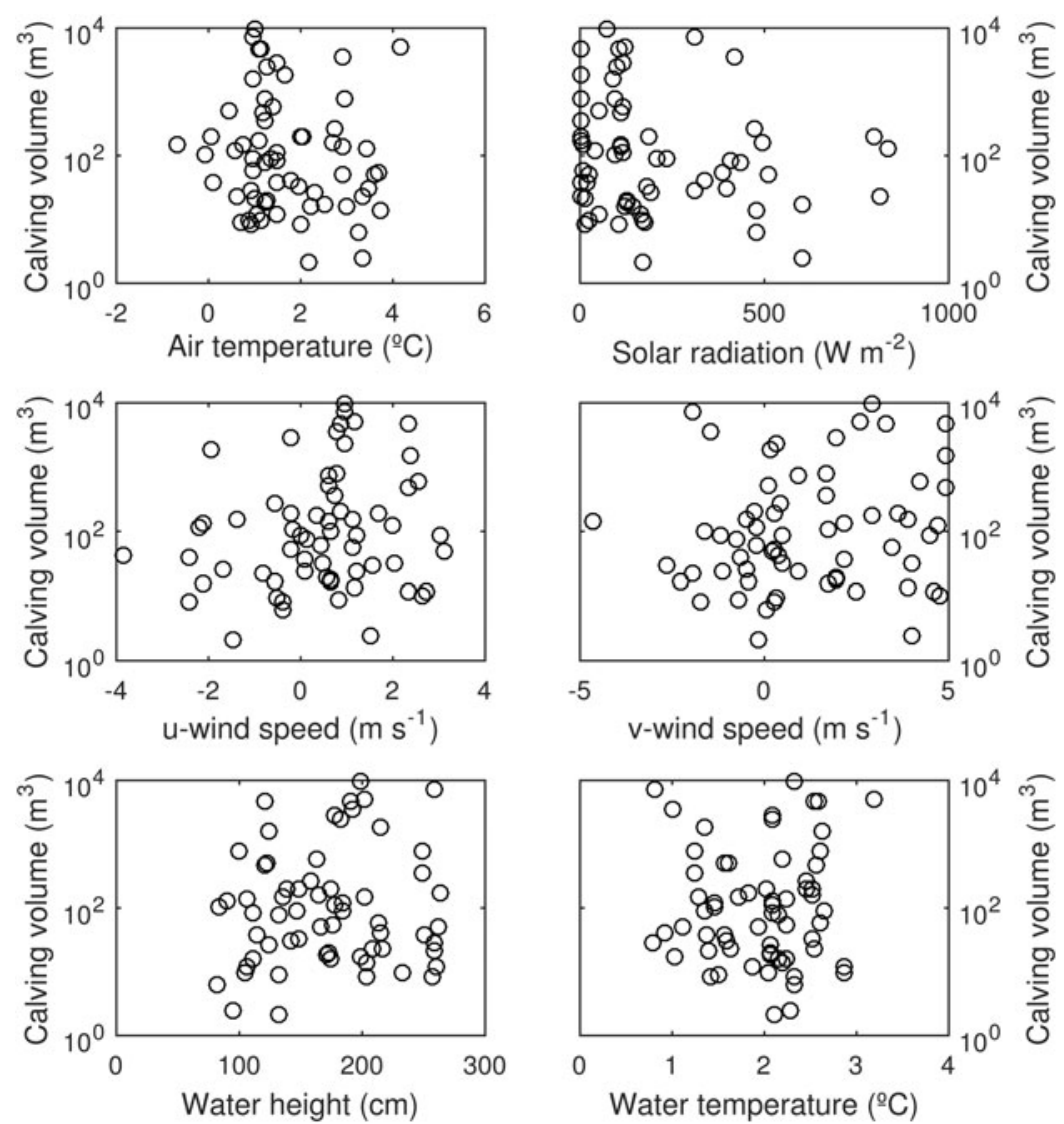

Fig. 12. Bivariate scatterplots of calving volumes against environmental variables. Wind speed convention: positive (negative) $u$ winds are from the west (east); positive (negative) $v$ winds are from the south (north).

be visually discernable between the occurrence and volume of calving events and any of the potential environmental drivers. In some, but not all instances of high air temperature, there does appear to be a relation between air temperature and calving volume. Stepwise logistic regression was used to examine whether any additive combination of the variables in Figure 10 could explain the probability of calving event occurrence. Although a significant $(p<0.05)$ relationship was found with air temperature (positive) and water height (negative), the generalized $R$ coefficient of determination was very low $\left(R^{2}=0.04\right)$. Hence, the occurrence of calving events does not seem to be significantly controlled by variations in the recorded environmental parameters, at least at the timescale considered (2 weeks). We also plotted calving volumes against each driver (Fig. 12) and could not find any simple bivariate relation. Stepwise linear regression of calving volume (log-transformed) against the six environmental variables yielded no significant relationships $(p>0.05)$.

Taken together these results support recent findings by Chapuis and Tetzlaff (2014), who showed that fluctuations in external environmental drivers are not required to explain the event-size and interval variability observed in field data over a 2 week period. While fluctuations in environmental drivers at larger timescale (seasonal and interannual) have been shown to have a clear influence on calving activity (e.g. Åström and others, 2014; Luckman and others, 2015), the occurrence and size distribution of calving events at the timescale considered in this study appears to result from internal, perhaps self organized, processes (Åström and others, 2014).

\section{CONCLUSIONS}

We have described a methodology for applying a combination of long-range TLS measurement and continuous video recording to monitor the calving activity of a tidewater glacier. It was successfully applied to short-term (14 d) observations of Fuerza Aérea Glacier. Throughout the observation time, the calving rate varied between $0.10 \pm 0.23$ and $1.74 \pm$ $0.25 \mathrm{~m} \mathrm{~d}^{-1}$, with a mean value of $0.41 \pm 0.07 \mathrm{~m} \mathrm{~d}^{-1}$. In total, 64 calving events of different size were identified, of which nine that did not occur from the same space on the calving cliff as others during the time interval between measurements were used for calving event area/volume scaling. The calving event size distribution is best approximated by a power-law distribution with a cut-off frequency at $1.5 \times 10^{3} \mathrm{~m}^{3}$. For the time span of the observations no clear relationship was found between the environmental forcings and calving activity, but calving was positively related to ice flow velocity. Therefore calving over such a short period of time appears to be governed by ice dynamics and seems to be an internal process of the ice front.

\section{ACKNOWLEDGMENTS}

We thank Sandro Zambra for valuable help in processing of video data, Jakob Abermann for his help in collection of data and the staff of Chilean Navy Antarctic Base Arturo Prat for logistic support during field work. This study was funded by the Chilean National Antarctic Institute (INACH) grant RT12_12 and, within statutory activities, Grant No. 3841/E$41 / S / 2016$ of the Ministry of Science and Higher Education 
of Poland. The publication has been partially financed by the Centre of Polar Studies from the funds of the Leading National Research Centre (KNOW) received for the period 2014-2018. We thank reviewers Ryan Cassotto and Roger LeB. Hooke for helpful comments.

\section{REFERENCES}

Amundson J and Truffer M (2010) A unifying framework for icebergcalving models. J. Glaciol., 56(199), 822-830

Arcos D and Salamanca MA (1980) Observaciones hidrográficas en Bahia Foster y Bahia Chile (Islas Shetland del Sur) enero 1978. Bolm Inst. oceanogr., S. Paulo, 29(2), 51-55

Åström JA and 6 others (2013) A particle based simulation model for glacier dynamics. Cryosphere, 7(5), 1591-1602

Åström JA and 10 others (2014) Termini of calving glaciers as selforganized critical systems. Nat. Geosci., 7(12), 874-878

Azhar H and Santana E (2007) Geology, glacial history and the evolving landscape of North Greenwich Island of the South Shetland Group of Islands of the Antarctic Peninsula, Sexto Simposio Argentino y Tercero Latinoamericano sobre investigaciones antárticas, Buenos Aires.

Bartholomaus TC, Larsen CF, O'Neel S and West ME (2012) Calving seismicity from iceberg-sea surface interactions. J. Geoph. Res. Earth Surf., 117(F4), F04029 (doi:10.1029/2012JF002513)

Bartholomaus TC and 5 others (2015) Tidal and seasonal variations in calving flux observed with passive seismology. J. Geophys. Res., 120(111), 2318-2337

Benn DI, Hulton NRJ and Mottram RH (2007a) 'Calving laws', 'sliding laws' and the stability of tidewater glaciers. Ann. Glaciol., 46, 123-130

Benn DI, Warren CR and Mottram RH (2007b) Calving processes and the dynamics of calving glaciers. Earth-Sci. Rev., 82, 143-179

Bliss A, Hock R and Cogley JG (2013) A new inventory of mountain glaciers and ice caps for the Antarctic periphery. Ann. Glaciol., 54(63), 191-199

Braun M and Hock R (2004) Spatially distributed surface energy balance and ablation modelling on the ice cap of King George Island (Antarctica). Glob. Planet. Change, 42(1), 45-58

Chapuis A and Tetzlaff T (2014) The variability of tidewater glacier calving: origin of event-size and interval distributions. J. Glaciol., 60(222), 622-634

Clauset A, Shalizi CR and Newman MEJ (2009) Power-law distributions in empirical data. SIAM Rev., 51(4), 661-703

Cook AJ, Fox AJ, Vaughan DG and Ferrigno JG (2005) Retreating glacier fronts on the Antarctic Peninsula over the past halfcentury. Science, 308(5721), 541-544

Deems JS, Painter TH and Finnegan DC (2013) Lidar measurements of snow depth: a review. J. Glaciol., 59(215), 467-479

Dowdeswell JA and Forsberg CF (1992) The size and frequency of icebergs and bergy bits derived from tidewater glaciers in Kongsfjorden, northwest Spitsbergen. Polar Res., 11(2), 81-91

Egli L, Jonas T, Grünewald T, Schirmer M and Burlando P (2012) Dynamics of snow ablation in a small Alpine catchment observed by repeated terrestrial laser scans. Hydrol. Process., 26(10), 1574-1585

Glowacki $O$ and 5 others (2015) Underwater acoustic signatures of glacier calving. Geophys. Res. Lett., 42(3), 804-812

Hartzell PJ, Gadomski P, Glennie CL, Finnegan DC and Deems JS (2015) Rigorous error propagation for terrestrial laser scanning with application to snow volume uncertainty. J. Glaciol., $6 \mathbf{1}$ (230), 1147-1158

Hock R, de Woul M, Radić V and Dyurgerov M (2009) Mountain glaciers and ice caps around Antarctica make a large sea-level rise contribution. Geophys. Res. Lett., 36(7), L07501 (doi: 10.1029/2008GL037020)

Hughes TJ and Nakagawa M (1989) Bending shear: the rate controlling mechanism for calving ice walls. J. Glaciol., 35(120), 260-266
Joughin I and MacAyeal DR (2005) Calving of large tabular icebergs from ice shelf rift systems. Geophys. Res. Lett., 32(2), L02501

Kejna M, Araźny A and Sobota I (2013) Climatic change on King George Island in the years 1948-2011. Polish Polar Res., 34(2), 213-235

Knap WH, Oerlemans J and Cadée M (1996) Climate sensitivity of the ice cap of King George Island, South Shetland Islands, Antarctica. Ann. Glaciol., 23, 154-159

Krug J, Weiss J, Gagliardini O and Durand G (2014) Combining damage and fracture mechanics to model calving. Cryosphere, 8(6), 2101-2117

Lowen SB and Teich MC (2005) Fractal-Based Point Processes, vol. $\mathbf{3 6 6}$ of Wiley Series in Probality and Statistics, John Wiley \& Sons, Hoboken, NJ

Luckman A and 5 others (2015) Calving rates at tidewater glaciers vary strongly with ocean temperature. Nat. Commun., 6, 8566

Murray T and 9 others (2015) Dynamics of glacier calving at the ungrounded margin of Helheim glacier, South-East Greenland. J. Geoph. Res. Earth Surf., 120(6), 964-982

Navarro FJ, Jonsell UY, Corcuera MI and Martin-Espanol A (2013) Decelerated mass loss of Hurd and Johnsons Glaciers, Livingston Island, Antarctic Peninsula. J. Glaciol., 59(213), 115-128

Nick FM, van der Veen C, Vieli A and Benn D (2010) A physically based calving model applied to marine outlet glaciers and implications for the glacier dynamics. J. Glaciol., 56(199), 781-794

Osmanoglu B, Braun M, Hock R and Navarro FJ (2013) Surface velocity and ice discharge of the ice cap on King George Island, Antarctica. Ann. Glaciol., 54(63), 111-119

Osmanoglu B, Navarro FJ, Hock R, Braun M and Corcuera MI (2014) Surface velocity and mass balance of Livingston Island ice cap, Antarctica. Cryosphere, 8(5), 1807-1823

Otero J, Navarro FJ, Martin C, Cuadrado ML and Corcuera MI (2010) A three-dimensional calving model: numerical experiments on Johnsons Glacier, Livingston Island. Antarctica. J. Glaciol., 56(196), 200-214

O'Neel S, Echelmeyer KA and Motyka RJ (2003) Short-term variations in calving of a tidewater glacier: LeConte Glacier, Alaska. J. Glaciol., 49(167), 587-598

O'Neel S, Larsen CF, Rupert N and Hansen R (2010) Iceberg calving as a primary source of regional-scale glacier-generated seismicity in the St. Elias Mountains, Alaska. J. Geophys. Res., 115, F04034

Passalacqua P and 15 others (2015) Analyzing high resolution topography for advancing the understanding of mass and energy transfer through landscapes: a review. Earth-Sci. Rev., 148, 174-193

Pẹtlicki M, Ciepły M, Jania JA, Promińska A and Kinnard C (2015) Calving of a tidewater glacier driven by melting at the waterline. J. Glaciol., 61(229), 851-863

Prokop A (2008) Assessing the applicability of terrestrial laser scanning for spatial snow depth measurements. Cold Reg. Sci. Technol., 54(3), 155-163

Rignot E, Jacobs S, Mouginot J and Scheuchl B (2013) Ice-shelf melting around Antarctica. Science, 341(6143), 266-270

Rignot E, Mouginot J, Morlighem M, Seroussi H and Scheuchl B (2014) Widespread, rapid grounding line retreat of Pine Island, Thwaites, Smith, and Kohler glaciers, West Antarctica, from 1992 to 2011. Geophys. Res. Lett., 41(10), 3502-3509

Rolstad C and Norland R (2009) Ground-based interferometric radar for velocity and calving-rate measurements of the tidewater glacier at Kronebreen, Svalbard. Ann. Glaciol., 50(50), 47-54

Rückamp M, Blindow N, Suckro S, Braun M and Humbert A (2010) Dynamics of the ice cap on King George Island, Antarctica: field measurements and numerical simulations. Ann. Glaciol., 51(55), 80-90

Rückamp M, Braun M, Suckro S and Blindow N (2011) Observed glacial changes on the King George Island ice cap, Antarctica, in the last decade. Glob. Planet. Change, 79(1), 99-109

Ryan JC and 7 others (2015) UAV photogrammetry and structure from motion to assess calving dynamics at Store Glacier, a large outlet draining the Greenland ice sheet. Cryosphere, 9(1), 1-11 
Santana E and Dumont JF (2007) Granulometry of pebble beach ridges in Fort Williams Point, Greenwich Island, Antarctic Peninsula; a possible result from Holocene climate fluctuations, Cooper, AK and CR Raymond, eds., Antarctica: A keystone in Changing World - Online Proceedings of the 10th ISAES, USGS Open-File Report 2007-1047, Short Research Paper 027

Schwalbe E, Maas H-G, Dietrich R and Ewert H (2008) Glacier velocity determination from multi-temporal long range laser scanner point clouds, The International Archives of the Photogrammetry, Remote Sensing and Spatial Information Sciences. ISPRS Congress Bejing, vol. XXXVII, 457-463

Simoes JC, Bremer UF, Aquino FE and Ferron FE (1999) Morphology and variations of glacial drainage basins in the King George Island ice field, Antarctica. Ann. Glaciol., 29(1), 220-224

Sobota I, Kejna M and Araźny A (2015) Short-term mass changes and retreat of the Ecology and Sphinx glacier system, King George Island, Antarctic Peninsula. Antarct. Sci., 27(05), 500-510

Sugiyama S, Sakakibara D, Tsutaki S, Maruyama M and Sawagaki T (2015) Glacier dynamics near the calving front of Bowdoin Glacier, northwestern Greenland. J. Glaciol., 61(226), 223-232
Turner J and 8 others (2005) Antarctic climate change during the last 50 years. Int. J. Climatol., 25(3), 279-294

van den Broeke M and 8 others (2009) Partitioning recent Greenland mass loss. Science, 326(5955), 984-986

van der Veen CJ (1996) Tidewater calving. J. Glaciol., 42(141), 375-385

Vaughan DG and 8 others (2003) Recent rapid regional climate warming on the Antarctic Peninsula. Clim. Change, 60(3), 243-274

Vieli A, Jania J and Kolondra L (2002) The retreat of a tidewater glacier: observations and model calculations on Hansbreen, Spitsbergen. J. Glaciol., 48(163), 592-600

Voytenko D and 5 others (2015) Tidally driven ice speed variation at Helheim Glacier, Greenland, observed with terrestrial radar interferometry. J. Glaciol., 61(226), 301-308

Westoby MJ, Brasington J, Glasser NF, Hambrey MJ and Reynolds JM (2012) 'Structure-from-Motion' photogrammetry: a low-cost, effective tool for geoscience applications. Geomorphology, 179, 300-314

WGMS (1989) World Glacier Inventory; Status (1988) A Contribution to the Global Environment Monitoring System (CEMS) and the International Hydrological Programme, Compiled by the World Glacier Monitoring Service. IASH Press, Zurich

MS received 14 December 2015 and accepted in revised form 2 April 2016; first published online 15 June 2016 